\title{
THE PREDICTION OF THE SUCCESS OF FIRST-YEAR MBA CANDIDATES: ONE BUSINESS SCHOOL AS A CASE STUDY
}

\author{
E. M. Scholtz* (correspondence) \\ North West Business School for Business and Governance \\ North West University Potchefstroom Campus \\ Potchefstroom, South Africa \\ e-mail: retha.scholtz@nwu.ac.za
}

\section{J. Pienaar}

North-West University

WorkWell Research Unit

Potchefstroom

e-mail: Jacobus.Pienaar@psychology.su.se

\section{ABSTRACT}

The focus of this study was to determine the best predictors of academic success of first-year MBA students. Selection criteria and variables are tested for the reliable prediction of successful completion of the first year of an MBA programme (MBAI). A longitudinal quantitative research design is followed using data of students from a South African business school, enrolled between the years 2006 and 2013. The study population consisted of a total of $N=777$ students enrolled on the MBA programme for this period. Numerical- and verbal cognitive ability assessments gathered as part of enrolment assessment were used and compared to MBAl examination results. Logistic regression analysis was used to determine the significance of different variables to predict MBA first-year success, defined here as the successful completion of all first-year MBA modules within the first academic year. Results indicate that cognitive ability is related to MBA first-year success. The numerical was a better predictor than the verbal cognitive assessment. Type of undergraduate education was found to play a role in MBA first-year success. Language of delivery proved to have an influence on academic performance and Younger students performed better than their older counterparts did. Determining the best predictors MBA first-year success has practical implications on selection processes and throughput.

Keywords: MBA, academic success, prediction, academic performance, pass-rate, cognitive ability, assessment, verbal ability, numerical, drop-out, selection practices

\section{INTRODUCTION}

Internationally, the popularity of a Master of Business Administration (MBA) has been evidenced in the escalation of MBA graduates over the last 50 years (Butler, Johnson and Forbes 2008). Even so, criticism of the MBA programme is ample, concerning factors such as 
selection practices, employability and career advancement of graduates, curricula as well as necessary skills offered (Mihail and Elefterie 2006; Navarro 2008; Dreher and Ryan 2002; Bennis and O'Toole 2005; Srikant et al. 2011).

To address the controversy towards MBA selection practices, some studies have been conducted to identify the most accurate approach in predicting academic performance in educational institutions, particularly those of business school graduates (Dreher and Ryan 2002; Bennett 2003; Furnham, Chamorro-Premuzic and McDougall 2003). These approaches include cognitive ability (Hoefer and Gould 2000; Dobson, Krapljan-Barr and Vielba 1999; Schwartz, Strowe and Sendall 2008; Hancock 1999; Hill et al. 2011; Terry, Owens and Cooley 2009; Kotze and Griesel 2008), personality (Van Bragt et al. 2011; DeSchields, Kara and Kaynak 2005; Chemers, $\mathrm{Hu}$ and Garcia 2001; Whittingham 2006), competency profiling (Adendorff and North 2004) and grade point average (GPA) (Schwartz et al. 2008; Christensen and Nance 2012; Braunstein 2006; Yang and Lu 2001).

Within the South African context, the challenges business schools face are similar to that of international business schools. One of the great concerns highlighted in recent years in South Africa concerns the throughput rate and academic performance of MBA students. The National Plan of the Ministry of Education required either education institutions to improve the efficiency of graduate outputs as a matter of priority (Ministry of Education 2001). Eleven years later, the Ministry of Higher Education observes in their annual report (2012), that massive investments in the higher education system have not produced better outcomes in the level of academic performance or throughput rates. However, the increased production of master's and doctoral graduates is essential in producing the next generation of academics and researchers.

Previous studies on academic performance and throughput rate found that the largest student dropout happens in the first year of study. Dreher and Ryan (2000) opine that the success of first-year MBA students holds consequences for the reputation of business schools, throughput rates and the design of curricula. McKenzie and Schweitzer (2001) studied the factors that influence academic performance of Australian first-year students and note factors such as increasing diversity among students and the expansion of Australian universities, with the objective to improve first-year pass rate. Bisschoff (2005) found the largest drop out in the first year of MBA studies in a South African business school, and notes this to be of great concern to the institution concerning throughput, financial implications and the negative impact financially and psychologically on students who fail the first year.

Against this background, selection processes and the accuracy of the selection criteria as predictors of MBA success have been in contention, resulting in some South African studies in search of answers to these problems (Adendorff and North 2004; Van der Merwe and De Beer 
2006; Kotze and Griesel 2008). South African business schools make use of different selection systems. Adendorf and North (2004) found that some merely select according to minimum admission requirements, while others use the Graduate Management Admissions Tests (GMAC 2012) in addition to the minimum admission requirements. Ability assessments (verbal critical reasoning and numerical critical reasoning) are used by the University of Stellenbosch Business School (USB 2017), Nelson Mandela Metropolitan University Business School (NMMU 2017), and the North-West University School of Business and Governance (NWU 2017). These trends are also evident in international business schools (Bisschoff 2005; Harvard Business School 2017; Stanford Graduate School of Business 2017). The link between these selection practices and actual academic success in the MBA programme is, however, not that firmly established.

Not many studies exist that firmly and empirically establish the link between selection measures and academic success, and only a few of these studies were within the South African context. As the first year proves critical (Bisschoff 2005), it is also noteworthy that not many studies focus specifically on the success of first-year MBA (MBAI) students. Further shortfalls in the available literature on this research topic are that these studies did not have an evidently strong research design including cognitive and verbal ability and the success of MBAI students, and were not done longitudinally. Past South Africa and International studies, was based on cross-sectional data and did not include predictors of MBA academic success. The current study will thus extend existing knowledge on the topic by investigating the predictors used in selection process, namely numerical and verbal cognitive assessments, and subsequent academic success. The present study's contribution is to address some of the noted shortfalls by making use of longitudinal data covering a period of eight years, measurements of both a cognitive and verbal ability assessment as predictors, and defines MBA success objectively, as indicated by the official MBA academic results for the indicated period.

\section{PREDICTORS OF MBA SUCCESS}

Success is a broad term that is frequently used in the educational environment to describe the mastering of numerous different academic outcomes (York, Gibson and Rankin 2015). For the purpose of this study, first-year MBA success is defined as the successful completion of all first-year MBA modules within the first academic year. The importance for business schools to enrol prospectively successful MBA students has been emphasised by several studies. In this regard, successfully completing the first year of study appears critical, as it is also the academic year that shows the highest levels of dropout from the MBA (Dreher and Ryan 2000; McKenzie and Schweitzer 2001; Bisschoff 2005). Several factors related to academic performance have been identified in the literature. Among the most prominent of these are cognitive ability, 
previous education, gender, language and age.

\section{Cognitive ability}

The most commonly used cognitive ability assessment in MBA selection internationally is the Graduate Management Admissions Test (GMAT). The GMAT assessment measures quantitative, verbal, analytical writing, and integrated reasoning skills. The Graduate Management Admission Council (GMAC 2012) describes the different components of the test as follows: The quantitative section measures ability to reason quantitatively and solve quantitative problems. Basic knowledge of arithmetic, algebra, and geometry is required. The quantitative section is a test of reasoning and not the underlying math skills. The verbal section measures ability to read and comprehend written material, to reason and evaluate arguments, and to correct written material to convey meaning effectively in standard written English. The analytical writing assessment measures ability to think critically and communicate ideas through writing. Finally, the integrated reasoning section measures ability to interpret and analyse data from different sources and presented in different formats, to solve problems.

Many studies have been conducted exploring the accuracy of the GMAT as a predictor of MBA success. Hill et al. (2011) and Terry et al. (2009) found the GMAT to be a reliable predictor. Similarly, Hoefer and Gould (2000) found the GMAT ability assessment to be a reliable predictor of academic performance, but suggest that qualitative predictors of performance should also be considered. Conversely, Dobson et al. (1999) found that GMATverbal is a good predictor of MBA examination performance, but that GMAT-quantitative is not. Schwartz et al. (2008) found a significant positive correlation between graduate GPA and the GMAT-quantitative score, while Clayton and Cate (2004) found GMAT played no role in MBA success. These inconclusive findings indicate that further research is necessary to determine the accuracy of prediction of academic performance by the GMAT specifically, but perhaps also cognitive ability more generally, as a predictor of academic performance.

Besides the GMAT, alternative cognitive assessment tools are available and applied by South African business schools as selection instruments. Within the South African context, Kotze and Griesel (2008) found verbal and numerical aptitude has a significant correlation with academic performance, of which numerical aptitude had higher significance. Adendorff and North (2004) found that both numerical and verbal skills were accurate predictors of MBA success.

\section{Focus of previous education}

The most prominent prerequisite for enrolment onto the MBA programme is a three- or four- 
year Bachelor's (undergraduate) degree. Ahmadi, Raiszadeh and Helms (1997) found that students with more than three years' undergraduate studies performed better academically than students with two years of undergraduate studies. Braunstein (2006) and Truitt (2002) explored whether students with majors in business studies performed better that students with nonbusiness qualifications, and found no difference in the academic performance of these two groups. Conversely, Sulaiman and Mohezar (2006) found that students with business and management qualifications performed better than students from other disciplines. Alias and Zain (2006) also found that type of undergraduate qualification is related to performance in graduate programmes and concludes that grade point average (GPA) in the same field of study is a better predictor than GPA from different fields of study.

Grade point average (GPA) as predictor of academic success in the MBA has commonly been used in selection processes for the MBA programme, even though the accuracy thereof has been shown to be inconsistent. Braunstein (2006) found the two most significant variables in predicting MBA academic performance to be GPA and the Graduate Management Admissions Test (GMAT). Yang and Lu (2001) found undergraduate grade point average (GPA) to be the most accurate predictor of MBA academic performance. Christensen and Nance (2012) support the finding of undergraduate GPA as an accurate predictor of MBA success, and also found undergraduate written composition to be positively correlated with GPA during the course of the MBA. Contrastingly, Truitt (2002) found that GPA was not statistically significant in the prediction of MBA academic performance. Given these somewhat inconsistent results, the authors opted to focus on prior education, rather than GPA, as predictor of success in MBAI.

\section{BIOGRAPHICAL CONTROLS FOR (ACADEMIC) SUCCESS}

In exploring gender differences in MBA performance, Hancock (1999) found that although men performed significantly better in a verbal selection assessment, there was no difference in MBA academic performance regarding gender. With this in mind, he contemplates that women might be at a disadvantage if the GMAT score were to be used as only admission requirement to the MBA programme. Hancock (1999) further argues that there is no strong case for the relationship between GMAT and MBA performance. Sulaiman and Mohezar (2006) also found that gender does not predict MBA success, nor ethnicity or age. In contrast, Ahmadi, Raizadeh and Helms (1997) found a positive correlation between age and academic performance; while gender and race were found to be insignificant variables.

Academic performance of international students and the language barrier they face have become a topic of interest for academic performance in post-graduate studies. According to 
Berman and Cheng (2001), language is a great challenge to international students at Englishspeaking universities, especially in the first year of study, resulting in lower academic performance. In support, Woodrow (2002) found that students within the Australian educational context with low English proficiency were negatively influenced in academic performance of first semester studies. Dooey and Oliver (2002) found that proficiency in English reading had an influence on academic success, but caution that language is not the only factor that influences the academic success of non-native English speakers. These findings have particular relevance to the South African situation, where the language of delivery at most tertiary institutions is English and a few in Afrikaans. South Africa is a multilingual country with a rich and diverse source of languages of which there are between 24 and 30 languages spoken. After 1994, with the birth of democracy, South Africa declared a policy of official multilingualism in its Constitution concerning language. Nine major African languages (isiNdebele, Sesotho sa Leboa, Sesotho, Siswati, Xitsonga, Setswana, Tshivenda, isiXhosa and isiZulu) together with English and Afrikaans were declared as official languages at national level (Finlayson and Madiba 2002). However, less than 10 per cent of the population has English as their first, and only 13.5 per cent Afrikaans, as their first language (Census 2011).

Based on the noted findings above, we opted to control for gender, age and language in our analysis. The objective of the current study is therefore to gain a deeper understanding of the academic success of MBAI students. The variables used to predict success is a measure of cognitive ability, focus of prior education, gender, home language and age.

\section{RESEARCH METHOD}

\section{Research design}

The study made use of a quantitative research design. A large data bank is available that can be quantified and summarised, and the final results will be expressed statistically. The data consists of statistics of MBA students enrolled at a business school between 2006 and 2013. Cognitive assessments have been part of the selection process for all MBA applicants from 2006, and will be compared to MBA academic results from 2006 to 2013. Various biographical indicators are available as controls.

\section{Measuring instruments}

A cognitive ability measure developed by SHL (founded by Saville and Holdsworth) was used as measuring instrument. The instrument consists of two questionnaires, assessing both numerical reasoning and verbal reasoning ability. 
Numerical reasoning: This questionnaire measures the ability to make correct decisions or inferences from numerical data. The data represented and the tasks set are relevant to a business environment. The emphasis in these tasks falls upon understanding and evaluating data, rather than upon computation. The questionnaire consists of 35 questions with a time limit of 35 minutes.

Verbal reasoning questionnaire: This questionnaire measures the ability to evaluate the logic of various kinds of arguments. The information presented is relevant to a business environment. The test emphasises understanding, using and evaluating verbal information rather than language usage, spelling or grammar. The questionnaire consists of 48 questions with a time limit of 25 minutes.

Studies were conducted to ensure that these instruments comply with South African legislation for validity, reliability and unbiased assessment (SHL 2009). The first validation study reported on, consisted of a sample that complied with the Employment Equity Act of 1998 to include African, coloured and Indian students of equal distribution (SHL 2009). Positive, statistically significant correlations of moderate to large effect size were found between the results of the numerical and verbal assessment in comparison with the MBA results of four modules (SHL 2009), proving the instruments to be reliable and appropriate for use in South Africa.

Biographical data was collected through the databank of enrolment at the specific business school for MBA students between the years 2006 to 2013. Students completed biographical details with application for enrolment onto the MBA programme. Variables analysed in this study include focus of previous education, gender, age and home language.

\section{Participants}

The total population of MBA first-year students of a South African business school enrolled for the academic years 2006 to 2013 is used for the research. A total of $N=777$ students represent the research population. Six full MBA cycles of MBA phase III had been completed in the time frame from June 2006 to November 2013, while eight phases of MBAI students had completed their first year. Table 1 portrays the population indicating the eight phases of MBAI students and drop-out rates in the different years of the MBA programme.

The largest drop-out of 289 students is lost from the first year of MBA to the second year. In the eight phases of MBAI of this study population, it amounts to 37 per cent, which has a significant influence on throughput figures of the programme. 
Table 1: Available study population: MBA cycles from 2006-2013 ( $N=777)$

\begin{tabular}{|c|c|c|c|c|c|c|c|c|}
\hline Years & 2006 & 2007 & 2008 & 2009 & 2010 & 2011 & 2012 & 2013 \\
\hline 1 & $\begin{array}{l}\text { MBA I } \\
n=91\end{array}$ & $\begin{array}{l}\text { MBA II } \\
n=70\end{array}$ & $\begin{array}{c}\text { MBA III } \\
n=58\end{array}$ & $\begin{array}{c}\text { MBA IV } \\
n=25\end{array}$ & & & & \\
\hline 2 & & $\begin{array}{c}\text { MBA I } \\
n=103\end{array}$ & $\begin{array}{l}\text { MBA II } \\
n=73\end{array}$ & $\begin{array}{c}\text { MBA III } \\
n=62\end{array}$ & $\begin{array}{c}\text { MBA IV } \\
n=20\end{array}$ & & & \\
\hline 3 & & & $\begin{array}{c}\text { MBA I } \\
n=103\end{array}$ & $\begin{array}{l}\text { MBA II } \\
n=84\end{array}$ & $\begin{array}{c}\text { MBA III } \\
n=72\end{array}$ & $\begin{array}{c}\text { MBA IV } \\
n=23\end{array}$ & & \\
\hline 4 & & & & $\begin{array}{c}\text { MBA I } \\
n=120\end{array}$ & $\begin{array}{l}\text { MBA II } \\
n=83\end{array}$ & $\begin{array}{c}\text { MBA III } \\
n=82\end{array}$ & $\begin{array}{c}\text { MBA IV } \\
n=17\end{array}$ & \\
\hline 5 & & & & & $\begin{array}{l}\text { MBA I } \\
n=79\end{array}$ & $\begin{array}{l}\text { MBA II } \\
n=73\end{array}$ & $\begin{array}{c}\text { MBA III } \\
n=67\end{array}$ & $\begin{array}{c}\mathrm{MBA} \text { IV } \\
n=18\end{array}$ \\
\hline 6 & \multirow{3}{*}{\multicolumn{3}{|c|}{$\begin{aligned} & \mathrm{n}(\mathrm{MBA} 1)=835 \\
& \mathrm{n}(\mathrm{MBA} 2)=546 \text { (289 drop outs) } \\
& \mathrm{n}(\mathrm{MBA})=413 \text { (133 drop outs) } \\
& n(\text { MBA4) }=103 \text { (did not complete } \\
& \quad \text { in } 3 \text { years) }\end{aligned}$}} & & & $\begin{array}{c}\text { MBA I } \\
n=108\end{array}$ & $\begin{array}{l}\text { MBA II } \\
n=81\end{array}$ & $\begin{array}{c}\text { MBA III } \\
n=72\end{array}$ \\
\hline 7 & & & & & & & $\begin{array}{c}\text { MBA I } \\
n=109\end{array}$ & $\begin{array}{l}\text { MBA II } \\
n=82\end{array}$ \\
\hline 8 & & & & & & & & $\begin{array}{c}\text { MBA I } \\
n=122\end{array}$ \\
\hline
\end{tabular}

\section{DATA ANALYSIS}

Statistical analysis was done with the aid of the SPSS program (SPSS 2017). Logistic regression analysis was used to determine the significance of numerical and verbal ability as predictors of successful completion of the first year of the MBA programme. Regression can be applied where Time 1 variables can be used to predict Time 2 outcomes. Logistic regression is particularly suited to cases where the outcome variable is on two levels - in our case, passing or failing the first year of the MBA programme. The analysis will focus on the relation of the cognitive and verbal ability measures, focus of previous education, gender, age and language to academic success over time (i.e. from 2006-2013). To determine which biographical variables should be included in the logistic regression, Chi-square tests for independence were used to explore the relationship between pass and fail, versus these categorical variables. If the p-value was less than or equal to the 0.05 level of significance, the variable was deemed to have significant influence on MBAI success, and was included in the logistic regression analysis.

The correlation between results of MBA first-year subjects and the results of cognitive ability was investigated using Pearson's product-moment correlation coefficient, thereby determining which variables are related to MBAI success.

Concerning previous education, it was decided to categorise these qualifications as numerically based- and non-numerically-based qualifications. The category of numericallybased qualifications is students with a BCom, BSc, BPharm, BSTA, BTech and LLB qualification, or a post-graduate level of qualification. Non-numerically-based qualifications are students with a BA in languages, communication, theology, philosophy, agriculture and education, which are not overwhelmingly based on numerical knowledge.

The authors' reasoning was that for specific categories (say BCom with Accounting), there were too few cases within small categories. Further motivation behind this was that previous 
studies identified that focus of prior education have an influence on academic performance of post-graduate studies (Truitt 2002; Braunstein 2006; Sulaiman and Mohezar 2006; and Alias and Zain 2006) as discussed under focus of previous education above.

The population of the study consisted of students with various languages as home language, namely English (128), Afrikaans (410) and various African languages of which Sesotho (77) and Setswana (50) had the largest representation. Following that, isiZulu (26) and isiXhosa (25) had large representation. For these and historical reasons, it was decided to categorise language as English and Afrikaans (category 1), and other languages (category 2).

\section{RESULTS}

\section{Biographical characteristics of study population}

Biographical data includes gender, home language, age, and educational qualification. Biographical characteristics of the study population are indicated in Table 2 below. Table 2 also provides information on the success (pass) or fail rate of the first year of the MBA.

Table 2: Biographical characteristics of the study population $(\mathrm{N}=777)$

\begin{tabular}{|c|c|c|c|c|c|c|}
\hline & \multicolumn{2}{|c|}{$\begin{array}{l}\text { MBA FIRST-YEAR } \\
\text { SUCCESS }\end{array}$} & \multirow[t]{2}{*}{ p-value } & \multirow[t]{2}{*}{ Cramer's V } \\
\hline & & & Pass & Fail & & \\
\hline \multirow[t]{2}{*}{ Gender } & Male & $\begin{array}{l}556 \\
72 \%\end{array}$ & $\begin{array}{c}178 \\
80.5 \%\end{array}$ & $\begin{array}{c}43 \\
19.5 \%\end{array}$ & \multirow[t]{2}{*}{.918} & \multirow[t]{2}{*}{.004} \\
\hline & Female & $\begin{array}{l}221 \\
28 \%\end{array}$ & $\begin{array}{c}446 \\
80.2 \%\end{array}$ & $\begin{array}{c}110 \\
19.8 \%\end{array}$ & & \\
\hline \multirow[t]{2}{*}{ Language } & $\begin{array}{l}\text { English/Afrikaans first } \\
\text { language }\end{array}$ & $\begin{array}{l}646 \\
83 \%\end{array}$ & $\begin{array}{c}527 \\
82.0 \%\end{array}$ & $\begin{array}{l}119 \\
18.4\end{array}$ & \multirow[t]{2}{*}{$<0.001$} & \multirow[t]{2}{*}{.229} \\
\hline & Other first language & $\begin{array}{l}131 \\
17 \%\end{array}$ & $\begin{array}{c}97 \\
74.0 \%\end{array}$ & $\begin{array}{c}34 \\
26.0 \%\end{array}$ & & \\
\hline \multirow[t]{6}{*}{ Age category } & $20-25$ & $\begin{array}{c}47 \\
6.04 \%\end{array}$ & $\begin{array}{c}42 \\
89.4 \%\end{array}$ & $\begin{array}{c}5 \\
10.6 \%\end{array}$ & \multirow{6}{*}{$<.001$} & \multirow{6}{*}{.212} \\
\hline & $26-30$ & $\begin{array}{c}202 \\
25.9 \%\end{array}$ & $\begin{array}{c}178 \\
88.1 \%\end{array}$ & $\begin{array}{c}24 \\
11.9 \%\end{array}$ & & \\
\hline & $31-35$ & $\begin{array}{c}185 \\
23.8 \% \\
\end{array}$ & $\begin{array}{c}148 \\
80.0 \%\end{array}$ & $\begin{array}{c}37 \\
20 \% \\
\end{array}$ & & \\
\hline & $36-40$ & $\begin{array}{c}177 \\
22.7 \%\end{array}$ & $\begin{array}{c}145 \\
81.9 \%\end{array}$ & $\begin{array}{c}32 \\
18.1 \%\end{array}$ & & \\
\hline & $41-45$ & $\begin{array}{c}96 \\
12.3 \% \\
\end{array}$ & $\begin{array}{c}70 \\
72.9 \% \\
\end{array}$ & $\begin{array}{c}26 \\
27.1 \% \\
\end{array}$ & & \\
\hline & $46-60$ & $\begin{array}{c}70 \\
9.0 \%\end{array}$ & $\begin{array}{c}41 \\
58.6 \%\end{array}$ & $\begin{array}{c}29 \\
41.4 \%\end{array}$ & & \\
\hline \multirow[t]{2}{*}{$\begin{array}{l}\text { Former } \\
\text { education }\end{array}$} & $\begin{array}{l}\text { Numerically-based } \\
\text { qualification }\end{array}$ & $\begin{array}{c}369 \\
47.4 \%\end{array}$ & $\begin{array}{c}308 \\
83.5 \%\end{array}$ & $\begin{array}{c}61 \\
16.5 \%\end{array}$ & \multirow[t]{2}{*}{.004} & \multirow[t]{2}{*}{.138} \\
\hline & $\begin{array}{l}\text { Non-numerical } \\
\text { qualifications }\end{array}$ & $\begin{array}{c}78 \\
10.0 \%\end{array}$ & $\begin{array}{c}54 \\
30.8 \%\end{array}$ & $\begin{array}{c}24 \\
30.8 \%\end{array}$ & & \\
\hline
\end{tabular}

Of the 777 participants, 28 per cent were female and 72 per cent male. Of the 221 females, 80.2 per cent passed the first year of the MBA programme, while 19.8 per cent failed. Of the 556 males, 80.5 per cent passed and 19.5 per cent failed. A Chi-square test for independence 
indicated no significant association $(p=0.918)$ between gender and success in the first year of the MBA. Therefore, gender was not further considered as a predictor.

\section{Language}

Of the $777(\mathrm{~N}=777)$ participants, the home languages of English or Afrikaans represent 83 per cent of the sample, while 17 per cent of the home languages were other than English or Afrikaans. Of the students with English or Afrikaans as home language, 82 per cent passed the first year of the MBA programme and 18.4 per cent failed. Of the students with other home language than English or Afrikaans, 74.0 per cent passed, and 26 per cent failed. A Chi-square test for independence $(p<0.001)$ and Cramer's V at .229 indicated an association with medium effect between language and MBAI success, so that students with English or Afrikaans had a significantly lower representation in the fail category.

\section{Age}

Of the $777(\mathrm{~N}=777)$ MBAI students, $47(6.04 \%)$ were between the ages of 20 and 25, 202 $(25.9 \%)$ were between the ages 26 and 30, 185 (238\%) were between the ages 31 and 35, 177 (22.75) were between ages 36 and 40, 96 (12.3\%) were between ages 41 and 45 and 70 (9.0\%) between ages 46 and 60 . The age group between 26 and 30 is the largest component of $25.9 \%$ of the population, while the smallest component of students was between the ages 46 and 60 . The results show that the pass rate of the youngest students, between 20 and 25, is the highest pass rate $(89.4 \%)$, while the pass rate of age category 46 and 60 is the lowest (58.6\%). A Chisquare test for independence $(p<0.001)$ and Cramer's V value of .212 for age indicate a medium significant association between age and MBAI success, so much so that younger individuals were more likely to be successful.

\section{Focus of previous education}

Of the $777(\mathrm{~N}=777)$ participants, $369(47.4 \%)$ had what was categorised as a numerically-based qualification, while $78(10.0 \%)$ had non-numerical qualifications. Of the 369 students with numerically-based qualifications, 83.5 per cent passed and 16.5 per cent failed. Of the 78 participants with qualifications classified as non-numerical, 69.2 per cent passed and 30.8 per cent failed. The students with numerically-based qualifications had the highest pass rate (83.5\%), while the pass rate of students with non-numerical qualifications was 69.2 per cent. A Chi-square test for independence ( $p=0.004)$ and Cramer's V value of .138 for former education indicate a medium significant association between former education and MBAI success. 


\section{Relationship between variables and academic success}

Numerical cognitive ability, verbal cognitive ability and the average between the two were correlated separately to determine which of these assessments proved to be the most reliable predictor of MBAI success or failure. Next, correlations between the different first-year MBA subjects and cognitive and verbal ability, and their average are computed, in order to investigate which ability relates to which subjects as portrayed in Table 3 .

Table 3: Correlation between results of MBAI examination and cognitive and verbal ability, and their average

\begin{tabular}{|c|c|c|c|c|}
\hline & & $\begin{array}{c}\text { Numerical cognitive } \\
\text { assessment }\end{array}$ & $\begin{array}{l}\text { Verbal cognitive } \\
\text { assessment }\end{array}$ & $\begin{array}{c}\text { Average between } \\
\text { numerical- and verbal } \\
\text { cognitive assessment }\end{array}$ \\
\hline \multirow{3}{*}{$\begin{array}{l}\text { Financial } \\
\text { accounting }\end{array}$} & Pearson correlation & $.523^{* *}$ & $.231^{* *}$ & $.456^{\star \star}$ \\
\hline & Sig. (2-tailed) & .000 & .000 & .000 \\
\hline & $\mathrm{N}$ & 718 & 715 & 720 \\
\hline \multirow{3}{*}{$\begin{array}{l}\text { Managerial } \\
\text { statistics }\end{array}$} & Pearson correlation & $.481^{\star *}$ & $.303^{* *}$ & $.460^{\star *}$ \\
\hline & Sig. (2-tailed) & .000 & .000 & .000 \\
\hline & $\mathrm{N}$ & 718 & 715 & 720 \\
\hline \multirow{3}{*}{$\begin{array}{l}\text { Organisational } \\
\text { behaviour }\end{array}$} & Pearson correlation & $.337^{* *}$ & $.263^{* *}$ & $.327^{\star *}$ \\
\hline & Sig. (2-tailed) & .000 & .000 & .000 \\
\hline & $\mathrm{N}$ & 718 & 715 & 720 \\
\hline \multirow[t]{3}{*}{ Labour relations } & Pearson correlation & $.373^{* *}$ & $.222^{* *}$ & $.337^{* *}$ \\
\hline & Sig. (2-tailed) & .000 & .000 & .000 \\
\hline & $\mathrm{N}$ & 718 & 715 & 720 \\
\hline \multirow{3}{*}{$\begin{array}{l}\text { Information } \\
\text { management }\end{array}$} & Pearson correlation & $.327^{* *}$ & $.243^{* *}$ & $.321^{* *}$ \\
\hline & Sig. (2-tailed) & .000 & .000 & .000 \\
\hline & $\mathrm{N}$ & 717 & 714 & 719 \\
\hline \multirow{3}{*}{$\begin{array}{l}\text { Managerial } \\
\text { economics }\end{array}$} & Pearson correlation & $.433^{* *}$ & $.291^{* *}$ & $.423^{* *}$ \\
\hline & Sig. (2-tailed) & .000 & .000 & .000 \\
\hline & $\mathrm{N}$ & 716 & 713 & 718 \\
\hline
\end{tabular}

\footnotetext{
*. Correlation is significant at the 0.05 level (2-tailed).
}

**. Correlation is significant at the 0.01 level (2-tailed).

The results as portrayed in Table 3 indicate a large positive correlation between numerical cognitive ability and Financial accounting with a coefficient of $r=.523$, which is significant at $p<.001$ (as indicated by the double asterisk after the coefficient). The relationship between the numerical cognitive assessment and the rest of the subjects has medium strength and is significant at $p<.001$. The correlation between the verbal numerical assessment and the firstyear MBA subjects indicates a small correlation between verbal cognitive assessment and the rest of the subjects with the lowest correlation of $r=.222$ with Labour relations and the highest correlation with Managerial economics with $\mathrm{r}=.291$, which are also significant at $p<.001$.

In Table 4, the predictive value of age, language, former education, and verbal and numerical cognitive assessments towards academic success was examined. 
Table 4: Logistic regression prediction likelihood of passing MBAI with numerical cognitive assessment as predictor of MBAI success

\begin{tabular}{|l|c|c|c|c|c|c|c|c|}
\hline \multicolumn{1}{|c|}{$\begin{array}{c}\text { Variables in the } \\
\text { equation }\end{array}$} & B & S.E. & Wald & df & Sig. & $\begin{array}{c}\text { Odds } \\
\text { ratio }\end{array}$ & \multicolumn{2}{c|}{$\begin{array}{c}\text { 95.0\% C.I. for odds } \\
\text { ratio }\end{array}$} \\
\hline Age & -0.228 & 0.095 & 5.759 & 1 & $0.016^{*}$ & 0.796 & 0.661 & 0.959 \\
\hline Language & 0.152 & 0.319 & 0.227 & 1 & 0.633 & 1.165 & 0.623 & 2.178 \\
\hline Former education & -0.599 & 0.326 & 3.375 & 1 & $0.066^{*}$ & 0.549 & 0.290 & 1.041 \\
\hline $\begin{array}{l}\text { Numerical cognitive } \\
\text { assessment }\end{array}$ & 0.858 & 0.191 & 20.249 & 1 & $0.000^{*}$ & 2.359 & 1.623 & 3.429 \\
\hline Constant & 2.535 & 0.462 & 30.097 & 1 & 0.000 & 12.617 & & \\
\hline
\end{tabular}

* Significant at the 0.05 level

Direct logistic regression was performed to assess the predictive value of five independent variables (age, language, former education and numerical cognitive assessment as predictor of MBAI success). The results in Table 4, regarding age, indicate that the chances of a student to pass the first year of MBA were 0.796 more for each age category (see Table 2) that a student is younger, which is statistically significant although the odds ratio is not practically important. The numerical cognitive assessment indicated that with every 1 mark scored higher in the assessment, students had a 2.359 higher chance to pass the first year of MBA, which is statistically significant and would also result in an important effect in practice for a larger increase in marks.

In Table 5, the predictive value of age, language, former education, and verbal and numerical cognitive and the average of cognitive assessment and verbal cognitive assessments towards academic success were examined.

Table 5: Logistic regression prediction likelihood of passing MBA I with verbal cognitive assessment as predictor of MBAI success

\begin{tabular}{|l|c|c|c|c|c|c|c|c|}
\hline \multicolumn{1}{|c|}{$\begin{array}{c}\text { Variables in the } \\
\text { equation }\end{array}$} & B & S.E. & Wald & df & Sig. & $\begin{array}{l}\text { Odds } \\
\text { ratio }\end{array}$ & \multicolumn{2}{c|}{$\begin{array}{c}95.0 \% \text { C.I. for odds } \\
\text { ratio }\end{array}$} \\
\hline Age & -0.244 & 0.094 & 6.722 & 1 & $0.010^{*}$ & 0.783 & 0.652 & 0.942 \\
\hline Language & 0.728 & 0.289 & 6.325 & 1 & $0.012^{*}$ & 2.071 & 1.174 & 3.651 \\
\hline Former education & -0.811 & 0.320 & 6.425 & 1 & $0.011^{*}$ & 0.444 & 0.237 & 0.832 \\
\hline $\begin{array}{l}\text { Verbal cognitive } \\
\text { assessment }\end{array}$ & 0.374 & 0.150 & 6.189 & 1 & $0.013^{*}$ & 1.454 & 1.083 & 1.952 \\
\hline Constant & 2.113 & 0.437 & 23.358 & 1 & 0.000 & 8.271 & & \\
\hline
\end{tabular}

* Significant at the 0.05 level

Direct logistic regression was performed to assess the predictive value of five independent variables (age, language, former education and verbal cognitive assessment) as predictor of MBAI success. The results in Table 5, regarding age, indicate that the chances of a student to pass the first year of MBA were 0.783 more for each age category that a student is younger, 
which is statistically significant, but the odds ratio is not practically important. Language as predictor of MBAI success indicates that the chances to pass were 2.071 higher for students with English or Afrikaans as home language - which is statistically significant, and the odds ratio of practical importance. Regarding former education, the indication is that students with numerically-based qualifications had a 0.444 higher chance to pass the first year of MBA compared to students with a numerical qualification, and that this is statistically significant. The verbal cognitive assessment indicated that with every 1 mark scored higher in the assessment, students had 1.454 a higher chance to pass the first year of MBA, which is statistically significant and would also result in an important effect in practice for a larger increase in marks. Results for language indicate that students with English and Afrikaans as home language were 2.071 times more likely to be in the pass category than students of other languages.

Table 6 presents the predictive value of age, language, former education, and the average of the numerical- and verbal cognitive assessments towards academic success.

Table 6: Logistic regression prediction likelihood of passing MBAI with the average of numerical and verbal cognitive assessment as predictor of MBAI success

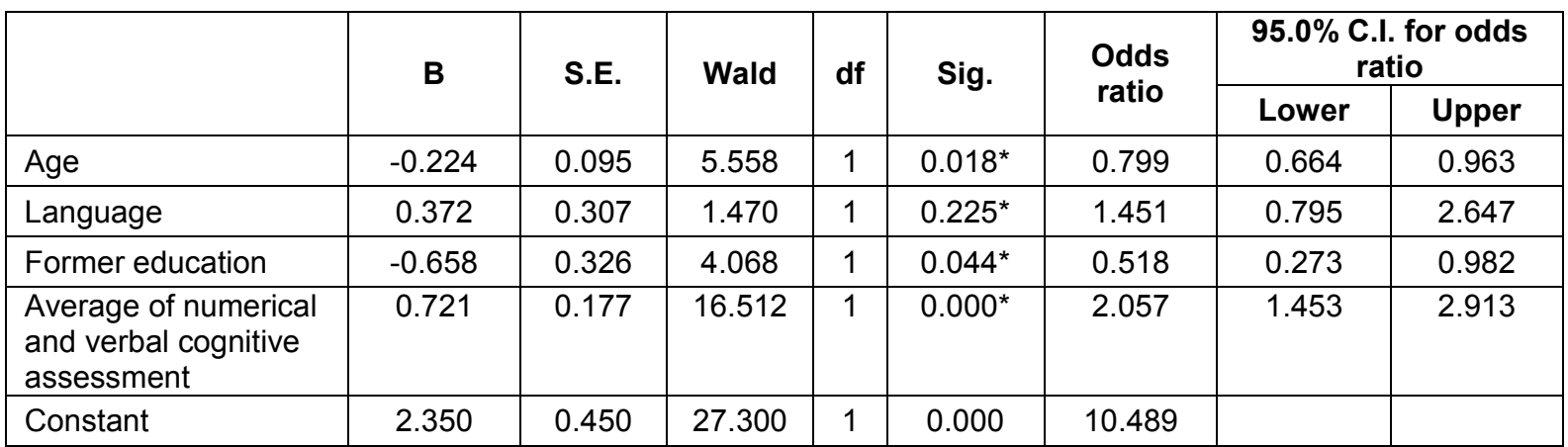

*Significant at the 0.05 level

The results in Table 6 , regarding age, indicate that the chances of a student to pass the first year of MBA were 0.799 more for each year that a student is in a lower age category. The result was statistically significant, although not practically important. Language as predictor of MBAI success indicates that the chances to pass were 1.451 higher for students with English or Afrikaans as home language, which is statistically significant and the odds ratio of practical importance. Regarding former education, the indication is that students with numerically-based qualifications had a 0.518 higher chance to pass the first year of MBA than students with a numerical qualification, which is statistically significant, but the odds ratio is not of practical importance. The average of the numerical and verbal cognitive assessment indicated that with every 1 mark scored higher on average in the assessment, students had a 2.057 times higher chance to pass the first year of MBA, which is statistically significant and would also result in an important effect in practice for a larger increase in marks. 


\section{DISCUSSION}

The aim of this study was to determine the predictors of MBAI success and explore current selection processes and prerequisites to the MBA programme. Precedent variables used in selection processes are controversial and results in literature exploring reliable predictors of MBA success proved to be inconclusive. Very few studies in this field focus on MBA first-year success. Data from the current study showed that the largest dropout in the MBA programme occurs in the first year of MBA (as portrayed in Table 1), which served as further motivation for the study.

Cognitive ability is widely used as selection instrument for MBA programmes. The current study confirms cognitive ability to be a reliable predictor of MBA first-year success. After assessing the predictive value of the verbal cognitive assessment, numerical cognitive assessment and the average of cognitive- and numerical cognitive assessments towards academic success were examined, the numerical cognitive assessment as variable proved to have the highest odds ratio overall in terms of of MBAI success. This is in line with previous South African findings by Kotze and Griesel (2008). Overall, this supports literature that found cognitive ability to be an accurate predictor of MBA academic performance (Hill et al. 2011; Terry et al. 2009; Clayton and Cate 2004; Hoefer and Gould 2000; Schwartz et al. 2008).

Regarding biographical predictors of MBA1 success, age was found to be statistically significant in all the analyses, and although the odds ratio was not practically important, younger students consistently fared better than older students did. Peiperl and Trevelyan (1997), and Ahmadi, Raiszadeh and Helms (1997), argue that younger students have been subjected to an academic environment more recently, which could be the explanation for them performing better than older students. This contradicts the belief that older MBA students have more to contribute in experience and knowledge and that work experience adds value to academic performance. Ekpenyong (2000) also found that younger students performed better in a Nigerian study with age and experience as covariates. The study found no difference in academic performance between male and female students, echoing much previous research (Dreher and Ryan 2000; Dreher and Ryan 2004; Sulaiman and Mohezar 2006).

This study confirmed former education to be a reliable predictor to MBA1 success. The indication was that students with a Bachelor's qualification in numerically-based subjects (defined as students with a BCom, BSc, BPharm, BSTA, BTech, LLB, master's and PhD qualifications, which all have a broad base of numerically-based knowledge) had a significantly better chance to pass the first year of MBA than students with non-numerically-based qualifications (defined as students with BA in languages, communication, theology philosophy, agriculture and education, which are not based on numerical knowledge). This supports the 
findings of Sulaiman and Mohezar (2006), and Alias and Zain (2006). The curriculum of the MBA1 programme of the study population of the current study has three numerically-based modules, namely Financial accounting, Managerial statistics and Managerial economics. This could have had an influence on the MBA1 pass rate of students with former qualifications in non-numerically-based fields of study.

Belonging to the English and Afrikaans language group was identified as a factor that influenced academic success in a South African business school. Firstly, this might not be as surprising, given that this is the dominant languages of instruction, despite national language demographics (Census 2011). This finding supports studies on English language proficiency and academic success within international contexts (Berman and Cheng 2001; Woodrow 2002; Dooey and Oliver 2002; Poyrazli et al. 2011; Stewart 2011). Educators are aware of the challenge these demographics bring in language of delivery at tertiary institutions (Finlayson and Madiba 2002), but clearly, much work remains to be done.

\section{RECOMMENDATIONS}

Selection criteria to predict MBAI success analysed in this study proved that some criteria in selection models were less reliable than others, which may suggest that selection processes of business schools need to be reviewed.

Cognitive ability as part of the selection programme used by many business schools proved to be a reliable and robust predictor of MBA academic performance. Numerical cognitive ability proved to be a better predictor than the verbal ability assessment, which might have a link to the curriculum and field of study of the MBA programme. It should especially be noted that in the evaluated programme, subject matter in the first year of study is also skewed towards numerical subjects (for example, Statistics and Accounting). A recommended solution might be a more equal spread of numerically-based modules of the MBA curriculum to improve the MBAI pass rate.

A bridging course in financial accounting is a further recommended for students with qualifications from qualitative fields of study in order to provide a basis in quantitative studies. Accordingly, focus of previous education also proved to have predictive value in terms of MBA success. Students with previous education in numerically-based fields of study had a better success rate than students from other fields of study. Firstly, the prerequisite of a Bachelor's degree in most MBA programmes is therefore supported. It may also be refined to be a Bachelor's degree with some minimal quantitative component (Statistics, for example), which could improve throughput and MBA academic success. It was further determined that the numerically-based modules had the largest failure rate of which Financial accounting posed to be the biggest obstacle. 
The findings of this study once again highlight the importance of language of delivery in education. It is recommended that the intellectualisation of the African languages is pursued further, as proposed by Finlayson and Madiba (2002), to ensure education in the mother tongue also becomes a reality at the MBA level. Simultaneous translation services in African languages can be proposed with the delivery of the programme, although some subject terminology could pose a problem (see Finlayson and Madiba 2002).

The potential practical implications of the above recommendations for business schools are; the implementation of an adapted curriculum and phasing out of current curricula. The implementation of adapted selection criteria, providing bridging courses in financial accounting, a focus on the intellectualisation of African languages, or alternatively providing more widely translation services for non-English speaking students.

\section{LIMITATIONS OF THE STUDY}

The study population of this study was limited to one business school in South Africa. Therefore, results may not be generalised to all business schools at all times. However, the business school under investigation is internationally accredited and in line with international curriculums, standards and trends. Our findings are therefore meaningful for selection processes at many business schools.

One limitation also concerns our classification of previous education as numerical vs. nonnumerical. Firstly, we did not have this information for all participants in the sample, and the results are therefore based on a subset of the current sample. Furthermore, our classification is based on our best judgement, and not some objective classification.

\section{REFERENCES}

Adendorff, S. and C. North. 2004. Towards an MBA selection model: A South African case study. Management Today 20(8): 40-41.

Ahmadi, M., F. Raiszadeh and M. Helms. 1997. An examination of the admission criteria for the MBA programs: A case study. Education 00131172, 117(4).

Alias, M. and A. F. D. Zain. 2006 Relationship between entry qualifications and performance in graduate education. International Education Journal 7(3): 371-378. Shannon Research Press.

Bennet, R. 2003. Determinants of undergraduate student dropout rate in University Business Studies Department. Journal of Further and Higher Education 27(2): 124-141.

Bennis, W. and J. O'Toole. 2005. How business schools lost their way. Harvard Business Review May 2005, 83: 5.

Berman, R. and L. Cheng. 2001. "English academic language skills: Perceived difficulties by undergraduate and graduate students, and their academic achievement". Canadian Journal of Applied Linguistics 4(1-2): 25-40.

Bisschoff, C. A. 2005. A preliminary model to identify low-risk MBA applicants. SA Journal of Economic and Management Sciences 8(3): 300-310.

Braunstein, A. W. 2006. MBA academic performance and type of undergraduate degree possessed. 
College Student Journal 40(3): 685-586.

Butler, D., L. Johnson and B. Forbes. 2008. An examination of a skills-based leadership coaching course in an MBA program. Journal of Education for Business March/April: 227-232.

Census. 2011. http://www.statssa.gov.za/ (Accessed 14 August 2017).

Chemers, M. M., L. Hu and B. F. Garcia. 2001. Academic self-efficacy and first year college performance and adjustment. Journal of Educational Psychology 93(1): 55-64.

Christensen, D. G. and W. R. Nance. 2012. Academic performance in MBA programs: Do prerequisites really matter? Journal of Education for Business 87: 42-47.

Clayton, G. E. and T. Cate. 2004. Predicting MBA no-shows and graduation success with discriminate analysis. International Advances in Economic Research 10: 235-243.

DeSchields Jr. O. W., A. Kara and E. Kaynak. 2005. Determinants of business student satisfaction and retention in higher education: Applying Herzberg's two-factor theory. International Journal of Educational Management 19(2): 128-139.

Dobson, P., P. Krapljan-Barr and C. Vielba. 1999. An evaluation of the validity and fairness of the Graduate Management Admission Test (GMAT) used for MBA selection in a UK business school. International Journal of Selection and Assessment 7(3): 196-202.

Dooey, P. and R. Oliver. 2002. An investigation into the predictive validity of the IELTS test. Prospect 17: $36-54$.

Dreher, G. F. and C. Ryan. 2000. Prior work experience and academic achievement among first-year MBA students. Research in Higher Education 41(4): 505-525.

Dreher, G. F. and C. Ryan. 2002. Evaluating MBA program admission criteria: The relationship between pre-work MBA work experience and post-MBA outcomes. Research in Higher Education 43(6): 727-744.

Dreher, G. F. and C. Ryan. 2004. A suspect MBA selection model: The case against the standard work experience requirement. Academy of Management Learning \& Education 3(1): 87-91.

Ekpenyong, D. B. 2000. Empirical analysis of the relationship between students' attributes and performance: Case study. Journal of Financial Management \& Analysis 13(2): 54-63.

Finlayson, R. and M. Madiba. 2002. The intellectualisation of the indigenous languages of South Africa: Challenges and prospects, current issues in language planning 3(1): 40-61. DOI: $10.1080 / 14664200208668036$.

Furnham, A., T. Chamorro-Premuzic and F. McDougall. 2003. Personality, cognitive ability, and beliefs about intelligence as predictors of academic performance. Learning and Individual Differences 14: 49-66.

GMAC see Graduate Management Admission Council.

Graduate Management Admission Council. 2012. Guide to the use of GMAT.

Hancock, T. 1999. The gender difference: Validity of standardized admission tests in predicting MBA performance. Journal of Education for Business 75(2): 91-93.

Harvard Business School. 2017. Admissions: Application process. http://www.hbs.edu/mba/ admissions/application-process/Pages/default.aspx (Accessed 18 August 2017).

Hill, K. L., G. E. Hynes, M. P. Joyce and J. S. Green. 2011. GMAT AWA score as a predictor of success in managerial communication course. Business Communications Quarterly 74: 103-118.

Hoefer, P. and J. Gould. 2000. Assessment of admission criteria for predicting students' academic performance in graduate business programs. Journal of Education for Business March/April: 225229.

Kotze, M. and L. Griesel. 2008. Predicting the academic performance of MBA students by means of specific aptitudes and competencies. Journal for New Generation Sciences 6(2): 60-79.

McKenzie, K. and R. D. Schweitzer. 2001. Who succeeds at university? Factors predicting academic performance in first year Australian university students. Journal for Higher Education Research 
\& Development 20(1): 21-23.

Mihail, D. M. and K. A. Elefterie. 2006. Perceived effects of an MBA degree on employability and career advancement: The case of Greece. Career Development International 11(4): 352-361

Ministry of Education. 2001. Draft National Plan for Higher Education in South Africa. (February). Pretoria: Government Printer.

Ministry of Higher Education and Training. 2012. Annual Report, 1 April 2012 to 31 March 2013. Pretoria: Government Printer.

Navarro, P. 2008. The MBA core curricula of top-ranked US business schools: A study in failure? Academy of Management Learning \& Education 7(1): 108-123.

Nelson Mandela Metropolitan University Business School. 2017. MBA psychometric testing and interviews. http://mba.nmmu.ac.za/content/mba-psychometric-testing-interviews (Accessed 18 August 2017).

NMMU see Nelson Mandela Metropolitan University Business School.

North-West University School of Business and Governance. 2017. Selection tests. http://commerce.nwu.ac.za/business-and-governance/useful-information (Accessed 18 August 2017).

NWU see North-West University School of Business and Governance.

Peiperl, M. A. and R. Trevelyan, R. 1997. Predictors of performance at business school and beyond: Demographic factors and the contrast between individual and group outcomes. Journal of Management Development 16(5): 354-367.

Poyrazli, S., C. Arbona, R. Bullington and S. Pisecco. 2001. Adjustment issues of Turkish college students studying in the United States. College Student Journal 35(1): 52-62.

Schwartz, L., K. Strowe, and P. Sendall. 2008. Understanding the factors that contribute to graduate student success: A study of Wingate University's MBA program. Conference proceedings Academy of Business Education: 1-11.

SHL. 2009. Objective assessment in MBA selection. South Africa Research Series. SHL Group Limited.

SPSS Inc. 2017. IBM SPSS Statistics Version 25, Release 23.0.0, Copyright $($ IBM Corporation and its licensors. http://www-01.ibm.com/software/analytics/spss/

Srikant M., D. A. Datar, P. Garvin and G. Cullen. 2011. Rethinking the MBA: Business education at a crossroads. Journal of Management Development 30(5): 451-462.

Stanford Graduate School of Business. 2017. Admission process. https://www.gsb.stanford.edu /programs/mba/financial-aid/international-students/stanford-africa-mba-fellowship/application (Accessed 18 August 2017).

Sulaiman, A. and S. Mohezar. 2006. Student success factors: Identifying key predictors. Journal of Education for Business 81(6): 328-333. DOI: 10.3200/JOEB.81.6.328-333.

Truitt, T. C. 2002. Validity of selection criteria in predicting MBA success. CBFA Conference 2002.

Terry, N., J. K. Owens and J. W. Cooley. 2009. The impact of instruction mode on student performance in graduate financial management. The Journal of Human Resource and Adult Learning 5(1): 148154.

University of Stellenbosch Business School. 2017. Selection tests. http://www.usb.ac.za/ MBA/Pages/SHL-or-GMAT.aspx (Accessed 18 August 2017).

USB see University of Stellenbosch Business School.

Van Bragt, A. C, W. E. A. Bakx, C. M. Bergen and M. A. Croon. 2011. Higher Education 61: 59-75. DOI 10.1007/s10734-010-9325-7.

Van der Merwe, D. and M. de Beer. 2006. Challenges of student selection: Predicting academic performance. South African Journal of Higher Education 20(4): 547-562.

Whittingham, K. L. 2006. Impact of personality on academic performance of MBA students: Qualitative 
versus quantitative courses. Decision Sciences Journal of Innovative Education 4(2): 175-190.

Woodrow, L. 2002. Academic success of international postgraduate education students and the role of English proficiency. University of Sydney Papers in TESOL (1): 51-70.

Yang, B. and D. R. Lu. 2001 Predicting academic performance in management education: An empirical investigation of MBA success. Journal of Education for Business 77: 15-20.

York, T. T., C. Gibson and S. Rankin. 2015. Defining and measuring academic success. Practical Assessment, Research \& Evaluation 20(5) March 2015 (e-journal). 